\title{
Reclaiming the Past: Restoration of Personal and Communal History in Petals of Blood
}

\section{Simona Klimková}

Constantine the Philosopher University in Nitra, Slovakia

The implications of the colonialist discourse, which suggested that the colonized is a person "whose historical, physical, and metaphysical geography begins with European memory" (Thiong'o, 2009), urged postcolonial writers to correct these views by addressing the issues from their own perspectives. The themes of history and communal/national past thus play a prominent role in postcolonial literature as they are inevitably interwoven with the concept of communal identity. In Petals of Blood (1977), the Kenyan writer Ngũgĩ wa Thiong'o explores the implications of social change as brought about by the political and economic development during the post-independence period. This paper seeks to examine the crucial relation between personal and communal/national history and relate it to the writer's views of principal legacies of colonialism. As Thiong'o states: "My interest in the past is because of the present and there is no way to discuss the future or present separate from the past" (Thiong'o, 1975). Clearly, the grasping of the past and one's identification with it seems fundamental in discussing national development. As Ngũgĩ wa Thiong'o's narratives are always situated in the realm of political and historical context, blending fiction with fact, this paper also aims to elaborate on the implications of his vision.

\section{Keywords}

History; postcolonial literature; community; communal/national identity; resistance

A writer's subject matter is history: i.e. the process of man acting on nature and changing it and in so doing acting on and changing himself.

(Thiong'o, Writers 72)

The rootedness of postcolonial literature in the historical experience of colonized countries with imperialism posits the struggle over history as one 
of its most essential thematic concerns. Postcolonial literature is thus directly tied to historical discourse since it, in fact, emerged out of the need to address the historical happenings in writing. The anti-colonial struggle and the fight for independence present thematic building stones of early postcolonial narratives. Moreover, the tenacious insistence on historical enquiry, manifested by numerous postcolonial novels, presupposes a critical inspection of the past and willingness to acknowledge alternative accounts which contest the prevalent colonialist discourse. The idea of a single, homogenous narrative, encapsulating historical records of the (formerly) colonized communities, is thus supplanted by a revisionist approach to past events. In order to reclaim the past that has been muted and/or altered by the colonial power, postcolonial literature utilizes its creative space as a vital constituent of the national narrative.

The urgency to counter the notion of the colonized world as ahistorical resulted from the need of "the ruling elites of Europe [...] to project their power backward in time, giving it a history and legitimacy that only tradition and longevity could impart" (Said 16). For in a colonial context, it is the conqueror who "'makes history' and forcibly imposes his version of it, dismissing as myth what the conquered believe in" (Rigal Cellard 25). In that respect, the (formerly) colonized subject took to refuting the idea of a single, legitimate history, seen as a continuous succession of events, asserting its authority over other options. "Many writers have striven to demonstrate how colonialism suggests certain ways of seeing, specific modes of understanding the world and one's place in it that assist in justifying the subservience of colonized peoples to the (oft-assumed) 'superior', civilized order of the [...] colonisers" (McLeod 18). In the words of Ashcroft et al., "what it means to have a history is the same as what it means to have a legitimate existence: history and legitimation go hand in hand; history legitimates 'us' and not others" (355).

For that reason, postcolonial writers tend to question and challenge the "single narrative truth which was 'simply' the closest possible representation of events" (Ashcroft et al. 355) rendered from the perspective of the empire; in doing so they renegotiate and contest that representation by voicing alternative visions and depictions of historical happenings. In, what Walter Benjamin calls, "the fight for the oppressed past" (396), the postcolonial community sought out to oppose its distorted representation and to exercise power over its own (hi)story. Writers therefore often assumed the moral responsibility of revisiting and rewriting the past so that it would reflect their perspective. In that sense, postcolonial literature can be read in conjunction with other 
historiographical resources and can be regarded as a relevant accompaniment to historical narratives rendered from the perspective of the empire.

The process of revision, however, poses its own challenges. In The Muse of History, Derek Walcott claims that:

In time every event becomes an exertion of memory and is thus subject to invention. The further the facts, the more history petrifies into myth. Thus, as we grow older as a race, we grow aware that history is written, that it is a kind of literature without morality, that in its actuaries the ego of the race is indissoluble and that everything depends on whether we write this fiction through the memory of hero or of victim. (11)

Clearly, Walcott is aware that all historical records are ideologically motivated and therefore sees history as myth, as fiction which is subject to memory. Such an understanding of history enables the rethinking of all accounts of past although Walcott warns that servitude to the muse of history might result in a literature of recrimination and despair.

For the Kenyan writer Ngũgĩ wa Thiong'o, history represents a relevant subject matter of African, or postcolonial literature, one that he repeatedly scrutinizes in his own work. His fiction, which repeatedly examines Kenyan history and politics, has retained its social and political character throughout his whole literary career. His early novels, namely Weep Not, Child (1964), The River Between (1965) and A Grain of Wheat (1967), portray Kenyan experience with European colonialism, focusing particularly on the moment of resistance, embodied by the Mau Mau uprising. This rather controversial period of Kenyan history, that preceded the declaration of independence in 1963 , represents a crucial moment in Thiong'o's writing, one that functions as a uniting element on a national level. It is through the resistance struggle that the writer attempts to renegotiate Kenyan identity and provide an alternative rendering of its historical narrative.

In his later fiction, i.e., his novels Petals of Blood (1977) and Devil on the Cross (1980), Thiong'o turns his attention to more pressing problems of the postcolonial world which, in his view, continues to be oppressed by neo-colonial domination. Here, his writing is infused with harsh, unrelenting criticism of new political elites that collaborate with multinational corporations and continue the process of exploitation. In that respect, the post-independence world, which was originally associated with high hopes and optimistic visions of national regeneration, is portrayed as a mere continuation of colonial 
oppression. Clearly, Ngũgĩ wa Thiong'o's writing is deeply rooted in the realm of Kenyan social and political reality and it continuously provides a reflection of active social processes. Moreover, as it will be demonstrated later on in this paper, his narratives often challenge the current status quo and provide an alternative perspective for communal/national development.

In that sense, due to the writer's active involvement in political processes in his native Kenya, which even resulted in his imprisonment, Ngũgĩ wa Thiong'o is regarded as one of the key figures of Kenyan public life, one who frequently and unrelentingly voices his (often radical) opinions on national matters. Seeing history of the postcolonial world as distorted by the cultural needs of imperialism, he embraces the need for a historical revision as part of the writers' responsibilities. "For a long time African writers were seen - or Africans as a whole - were seen as having no vital culture and having no history. So the African writer's first job was, I think, to see the African society in the perspective of history" (Thiong'o in Sander and Lindfors 39).

In his book on Ngũgĩ wa Thiong'o, Patrick Williams quotes the Caribbean historian and journalist C.L.R. James as one of Thiong'o's major influences. James's book The Black facobins, which Thiong'o regards as revolutionary in terms of its handling of history, "is exemplary as an early work of radical revisionist historiography" (Williams 8). Looking for similarities between events happening in diverse geographical locations, James inspired Thiong'o to reconsider and challenge the findings of Kenyan historians and provide the public with his own rendition of national history. In that respect, the writer contributes to the creation and reconceptualization of national identity which is viewed not as a finite construct but rather as something "historically mutable" (Williams 18).

As a well-known advocate of socially committed writing that exercises the power of literature to contribute to social transformation, Ngũgĩ wa Thiong'o posits the writer directly into the centre of action. His views on writers' responsibilities concerning their influential role in social processes stem from his beliefs that writers act as active agents of vision, moral guidance and potential change. Though Thiong'o is aware that the real power to transform reality lies with the people, he nonetheless stresses the significance of literature in the process. Fiction, in his view, provides writers with the space to question, challenge and reimagine existing representations of the nation and its history and thus opens up to construction of alternative historiographies.

Thiong'o's fiction, therefore, does not aim to be historically mimetic. Instead, history is seen as a terrain that is open to reinterpretation and revision. 
The author problematizes the concept of historical meaning "by blurring boundaries between national and individual events, between factual history and fiction, thus throwing into question the process by which subjects position themselves in history and the ways they might conceive and tell the story" (Kessler 76 ). The novels not only document the history of the country, they also provide the author with the space to rewrite the history from the perspective of the formerly silent colonized subject who was believed to be deprived of his or her voice. "Ngugi posits narrative here as an agent of history because it provides the space for challenging our notions of national identities, uses of history, and ways in which they are deployed in power contestation in modern Kenya and Africa in general" (Ogude 2). His novels thus not only reconstruct the history of the country but also take the liberty to modify and mould the historical narrative in such a way that suits his artistic and political purposes (Klimková 157).

His views seem to correlate with Patrick Williams's understanding of national identity as a historical construct, one that is "constituted in particular by the (ideologically loaded) narratives which particular communities tell themselves about who and what they are" (18). Fiction, in that sense, embodies the potential of projecting one's vision of collective identity to a large audience and therefore contributes to the construction of national identity. The ideological motivation of such a projection, however, with "different groups [competing] for their narratives of the nation to become recognized and legitimized" (Williams 19), necessarily impacts the final outcome and needs to be taken into consideration. Inevitably, the writer's stance towards a certain historical epoch will mould the narrative accordingly.

History, both personal and national, features prominently in Thiong'o's writing. His early fiction, especially the novels Weep Not, Child and A Grain of Wheat, recounts the Kenyan struggle for independence and the experience with European colonialism, as articulated by individual local narratives. By rewriting the crucial moments of recent Kenyan history via a selection of interconnected personal stories, the writer revisits the past and counters the "simplistic European response to the African experience" (Thiong'o quoted in Sander and Lindfors 39) which often labelled the colonized culture as ahistorical. Here, Thiong'o shifts the focus to communal achievements and moments of heroism and bravery in order to reconceptualize national identity.

For Thiong'o, the defining and formative moment of Kenyan national character resides undoubtedly in the tradition of resistance. His writing 
repeatedly oscillates around the Mau Mau Uprising, using it as a powerful symbol of resilience and tenacity (though it is not portrayed uncritically) and installing it as an event central to Kenyan character and national identity. While his early fiction draws on the resistance against the colonial presence in Kenya, Petals of Blood, his seminal novel, steers the discussion towards the post-independence period of neo-colonial domination. Though the Mau Mau Uprising still features in the novel to a certain extent, the focus is placed primarily on individual, seemingly small-scale moments of resistance.

The novel's events revolve around four main protagonists - the schoolteacher Munira, the former guerrilla fighter Abdulla, now a shopkeeper, the barmaid/ prostitute Wanja and the young idealist Karega - who live in a small village called Ilmorog. Situated far from the bustling city of Nairobi, Ilmorog has to rely on its own resources and cope with any problems on its own. The exhilaration, which accompanied the newly acquired independence, is however soon transplanted by frustration and disappointment as the village is plagued by drought and subsequent famine. With the realization that the new rulers are keen on continuing the patterns of exploitation and favouring corporate interests and international businesses over the plight of the native population, the inhabitants of Ilmorog sink deeper into disillusionment.

Structured as a murder investigation, almost the entire novel is narrated through flashbacks. The question of the past, and not only of the recent past events leading to the murder of three African directors of a foreign-owned brewery, becomes inevitably one of the main concerns of the novel. Each of the four protagonists, who are eventually arrested as suspects, is trying to come to terms with his/her own past; and in the process, the story of Ilmorog, as well as that of Kenya, is reconstructed. Once again, Ngũgĩ wa Thiong'o weaves personal stories into a larger, historical narrative. The gradual uncovering of the intricate destinies of these particular characters gives him the opportunity to examine the national past and postulate some urgent questions about the future of the country.

The novel moves back and forth between the present, which comprises approximately ten days after the arrest of the main characters, and the past which goes back twelve years to the time when Munira first arrived to Ilmorog. "Moving backwards in time, there is colonial, pre-colonial and mythic history" (Williams 8o), moving forwards, the book touches upon the legacies of colonialism, such as "urbanisation; industrialisation; commodification of goods, process and people; exploitation; class formation; the relentless pursuit of profit; rural depopulation and immiseration" (81). Through the deployment 
of a complex time frame, the writer points to the mutual dependency of past and present events and the interconnectedness of seemingly irrelevant episodes. The temporal frame can be viewed as a literary expression of Thiong'o's stance towards the interpretation of the past which necessarily affects how people look at their future. In other words, "[a] distorted view of a people's past can very easily distort our views and evaluation of the present as well as the evaluation of our present potentials and our future possibilities as a people" (Thiong'o 86).

The desire to revisit Kenya's past is embodied by Karega whose initial idealism is mainly fuelled by his "vision of the future rooted in a critical awareness of the past" (Thiong'o, Petals 237). Seeing the unfairness and inadequacy of current wealth distribution, he first turns to history books in hope of finding answers to the dismal present situation. Soon enough, however, Karega realizes that "[ $\mathrm{t}]$ he learned one never wanted to confront the meaning of colonialism and of imperialism" (237). Political science does not provide any comfort either so he turns to imaginative literature. Though the writers "seemed able to reflect accurately the contemporary situation of fear, oppressions and deprivation", they "lead him down the paths of pessimism, obscurity and mysticism" (238).

Indeed, Petals of Blood is steeped in harsh criticism of the new black ruling class. The negative portrayals of its representatives - Nderi wa Riera (a member of parliament), Kimeria (a businessman) and Chui (the headmaster of Siriana) - validate not only Karega's pessimism but also the eventual resignation and frustration of the peasantry. The involvement of the elite in illegal and exploitative activities as well as their betrayal of their own ideals and values (like in the case of Chui, a former leader of a student revolt who returns to Siriana as headmaster and then instigates and sanctions oppression) documents the unflattering post-independence development. It is the continuing perpetuation of colonial practices and marginalization of the working masses by Kenya's own people who are collaborating with foreign capital that the writer holds responsible for the country's stagnation and the "eternal interminable cycle of destitution and deprivation" (377).

Just like the Trans-Africa Highway divides the community in Ilmorog, both geographically and symbolically, in two, so is the population of postindependence Kenya divided into those with power and those who are powerless. The dubious portrayal of the empowered few clearly aligns with Thiong'o's socialist opinions and his belief that " $[\mathrm{t}]$ he socialist system is the only system which stresses interdependence and the only system which 
encourages cooperation" (Thiong'o quoted in Sander and Lindfors 55). The neglected working class thus represents the true force of social transformation, although its mobilization poses quite a challenge in the novel. It is best exemplified by the collective initiative of Ilmorog inhabitants to undertake an arduous journey to Nairobi to visit their local MP to ask for help for the drought-stricken village.

The journey to Nairobi, "[ $\mathrm{t}]$ he exodus toward the kingdom of knowledge" (Petals 141), is met with unwillingness and refusal. The drought crisis is first addressed by elders who decide to sacrifice Abdulla's donkey and hope for the rain to come. Karega's restlessness, however, promptly presents a more pragmatic solution - to visit the MP. His plan, involving collective action of a unified community, is met with scepticism. But Nyakinyua, Wanja's grandmother and the oldest, most revered woman in Ilmorog, delivers a speech which forges the community spirit and inspires people to oppose the culture of victimization and take matters into their own hands. It is the invocation of a more prosperous past that functions as the catalyst of collective effort. "There was a time when things happened the way we in Ilmorog wanted them to happen. We had power over the movement of our limbs. We made up our own words and sang them and we danced to them" (Petals 138). Paradoxically, it is the journey to Nairobi that in the end brings modernity to the village and only aggravates the divisions in Ilmorog.

Nevertheless, the role of individual effort and responsibility, which seem to be the driving force of a prosperous community, is best exemplified by the opposite approaches of Munira and Karega. Munira's intentional passivity and detachment from social events posit him in the role of an outsider who is reduced to a mere spectator of social happenings. His reluctance to participate in public life is rooted in his resentment towards his father, a successful landowner who was regarded as a collaborator with the British colonizers. Throughout his life, Munira always stood on the side, isolated both from his family (father and wife) and society, questioning the rationale for involvement. "He had chosen not to choose, a freedom he daily celebrated" (Petals 85). At the same time, however, he experiences "the guilt of omission" (Petals 73) of not contributing his part to the prosperity of his country. Through the character of Munira, who "prefers the culture of silence to active political engagement", Ngũgĩ expresses his "sense of disillusionment with the intellectual elite in Kenya" (Ogude 82).

Similarly to Wanja, who is running away from a shameful past, Munira sees Ilmorog as an opportunity for a fresh start. "...everything about his past since 
Siriana was so vague, unreal, a mist... It was as if there was a big break in the continuity of his life and of his memories" (Petals 19). His decision to go to Ilmorog, despite its challenges, is seen as "his first conscious act of breaking with this sense of non-being" (19). Despite his wish to detach himself from his father and his own failures, Munira remains isolated within the realm of his classroom. Teaching provides him with a sort of personal contentment; this, however, proves inadequate when faced with acute communal crisis, requiring resolute action and leadership. In the end, Munira's decision to abandon his comfortable neutrality and passivity results in a misguided arson attack that kills three people.

Munira's escapism is sharply contrasted with Karega's fiery activism. His quest for "a world in which the wealth of our land shall belong to us all" (Petals 389 ) is first and foremost embodied in his teaching and his work with the young generation. His belief in the power of the youth, not weighed down by the burden of the past, is inspired by the student strike in Siriana:

I thought I saw a new youth emerging, a youth freed from the direct shame and humiliation of the past and hence not so spiritually wounded as those who had gone before [...] I said to myself: here is our hope...in the new children, who have nothing to prove to the white man... who do not find it necessary to prove that they can eat with knife and fork; that they can speak English through the nose; that they can serve the monster as efficiently as the white ministers; and therefore can see the collective humiliation clearly and hence are ready to strike out for the true kingdom of the black god within us all. (Petals 200)

Education, a topic also discussed in Thiong'o's previous novels, seems to be the answer to a more prosperous future. It is precisely the tradition of resistance that Karega associates with a new national consciousness that he wants to instil in his students. His social and political convictions, sometimes articulated in a rather propagandistic rhetoric, seem to correspond with Ngũgĩ wa Thiong'o's understanding of the role of peasantry and working class in a larger political scheme.

That Kenya people have had a history of fighting and resistance is [...] a fact. Our children must look at things that deformed us yesterday, that are deforming us today. They must also look at the things which formed us yesterday, that will creatively form us into a new breed of men and women 
who will not be afraid to link hands with children from other lands on the basis of an unashamed immersion in the struggle against those things that dwarf us. (Petals 294)

Though Karega realizes that his teaching was full of romantic ideas, he finds "the best self of the community, symbol of Kenya's truest courage" (Petals 271) in Abdulla. Karega's disillusionment with African historians is caused by their production of history that no one can be proud of. It is the inconspicuous shopkeeper who turns out to epitomize the spirit of resistance to him. Abdulla himself cast his unacknowledged glorious past as a freedom fighter away as soon as he realized that the fruits of his fight are not meant to be savoured by people like him. Yet for Karega, the individual efforts of freedom fighters and activists, fighting against oppression and exploitation, constitute the basis of a new national identity. It is the cumulative power of individual struggles that might, according to him, change the oppressive conditions of Kenyan people.

To conclude, the glimpse into the personal past of the main protagonists provides a necessary link between the private and public aspects of life in post-independence Kenya. All of the characters are connected in some way or another with national history and have taken their part in it. Yet not all of them know how to proceed further in order to stop the cycle of exploitation and powerlessness. Though the fiction of Ngũgĩ wa Thiong'o is often steeped in ideological talk, it is nevertheless emblematic of how Kenya was transformed since the 1950s. His persuasion that a critical study of the past can propel the country forward is also voiced by Karega: "[W]e must not preserve our past as a museum: rather, we must study it critically, without illusions, and see what lessons we can draw from it in today's battlefield of the future and the present. But to worship it - no" (Petals 384 ). Past is therefore seen as a living lesson for the present and as a building stone of a new national identity. Shifting the focus to the working class and its role in the historical scheme of events, as well as seeing the tradition of resistance as the crucial constituent of national identity, encapsulate Ngũgĩ wa Thiong'o's contribution to Kenyan historiography.

\section{Works Cited}

Ashcroft et al., (Eds.). The Post-Colonial Studies Reader. London/New York:

Routledge, 2003. E-book. 
Benjamin, Walter. Selected Writings. Volume 4. 1938-1940. Cambridge/London: The Belknap Press of Harvard University Press, 2003. Print.

Kessler, Kathy. "Rewriting History in Fiction: Elements of Postmodernism in Ngugi wa Thiong'o's Later Novel." Ariel. A Review of International English Literature. April 1994: 75-90. Print.

Klimková, Simona. "History and Fiction: Ngũgĩ Wa Thiong'o's Vision”. Studia Anglica Resoviensia. 2015: 154-161. Print.

McLeod, John. Beginning Postcolonialism. Manchester/New York: Manchester University Press, 2000. Print.

Ogude, James. Ngugi's Novels and African History. Narrating the Nation. London: Pluto Press, 1999. Print.

Rigal Cellard, Bernadette. "Plotting History: The Function of History in Native North American Literature." Transatlantic Voices. Interpretations of Native North American Literature. Ed. Elvira Pulitano. Lincoln/London: University of Nebraska Press, 2007. 24-43. Print.

Said, Edward. Culture and Imperialism. New York: Vintage Books, 1994. Print.

Sander, Reinhard and Bernth Lindfors, (Eds.). Ngũgĩ wa Thiong'o Speaks. Nairobi: James Currey Oxford, 2006. Print.

Thiong'o, Ngũgĩ wa. Writers in Politics. London: Heinemann, 1981. Print.

---. Petals of Blood. New York: Penguin Books, 2005. Print.

Walcott, Derek. What the Troilight Says. New York: Farrar, Straus and Giroux, 1998. Print.

Williams, Patrick. Ngugi wa Thiong'o. Contemporary World Writers. Manchester/ New York: Manchester University Press, 1999. Print.

\section{Acknowledgement}

This work was supported by a grant from the VEGA 1/o426/17 project Ikonizácia utrpenia a jeho zmyslu v slovesnom, umeleckom a kultúrnom obraze I (Intersemiotická, interdisciplinárna a medzikultúrna rekognoskácia).

SIMONA KLIMKOVÁ is an assistant professor at the Department of English and American Studies of the Constantine the Philosopher University in Nitra, Slovakia, where she lectures and teaches courses on British and postcolonial literature. Her research focuses primarily on the area of postcolonial studies and postcolonial writing. Dr. Klimková is the co-author of the following 
SIMONA KLIMKOVÁ

monographs: Cultural Encounters in Contemporary Literature, Multicultural Awareness: Reading Ethnic Writing and Literature and Culture.

sklimkova@ukf.sk 